\author{
MAREK KORNAT \\ Instytut Historii PAN, Warszawa
}

\title{
PIERWSZA ZDRADA ZACHODU. WOKÓŁ KSIĄŻKI ANDRZEJA NOWAKA*
}

\begin{abstract}
Abstrakt: Wojna polsko-sowiecka (19191920) była jednym z kluczowych wydarzeń w procesie kształtowania ładu wersalskiego w Europie Wschodniej. Umożliwiła ocalenie tego ładu. Dawał on zaś narodom Europy Środkowo-Wschodniej niezmiernie cenne dwadzieścia lat samostanowienia i budowy własnych państw narodowych na gruzach trzech imperiów, które uległy dezintegracji w następstwie rewolucji geopolitycznej, jaką wywołała Wielka Wojna (1914-1918). Od początku na Zachodzie nie było zrozumienia geopolitycznego znaczenia polsko-sowieckiego konfliktu, który jest najczęściej postrzegany jako lokalne starcie dwóch państw, wywołane przez „polski imperializm”.
\end{abstract}

Słowa kluczowe: Ład wersalski, wojna polsko-sowiecka 1919-1920, Wielka Brytania, appeasement, Andrzej Nowak.
Abstract: The Polish-Soviet War (19191920 ) is one of the key factors shaping the Versailles governance in Eastern Europe. Having saved implementation of the Treaty of Versailles, the war gave the nations of Central and Eastern Europe an extremely valuable opportunity, for twenty years, to decide about themselves and build their own national countries on the remnants of three empires, which disintegrated in the aftermath of the geopolitical revolution brought by the Great War (1914-1918). From the very beginning, the West did not understand the geopolitical significance of the Polish-Soviet War, seen as a local conflict of two countries, triggered by "Polish imperialism".

Keywords: Versailles order, Polish-Soviet War 1919-1920, Great Britain, appeasement, Andrzej Nowak.

Andrzeja Nowaka Pierwsza zdrada Zachodu. 1920 - zapomniany appeasement jest niewątpliwie podsumowaniem wieloletnich dociekań tego historyka wokół znaczenia wojny polsko-sowieckiej dla Polski, Europy i świata ${ }^{1}$. Powstała w ten

* Andrzej Nowak, Pierwsza zdrada Zachodu. 1920 - zapomniany appeasement, Wydawnictwo Literackie, Kraków 2015, ss. 603.

1 Genezie wojny polsko-sowieckiej poświęcił on monografię: Polska i trzy Rosje. Studium polityki wschodniej Józefa Piłsudskiego (do kwietnia 1920 roku), Kraków 2001. 
sposób książka doniosła pod względem naukowym, skłaniająca do rozmaitych przemyśleń. Nasuwa wiele pytań. Spełnia w ten sposób wzorowo swoje zadanie jako monografia naukowa, której narracja jest próbą rozwiązania istotnego problemu badawczego, w oparciu o nowe źródła, mimo znacznego już dorobku historiografii.

Podstawę źródłową pracy stanowią głównie akta brytyjskie. Oprócz akt Gabinetu i Foreign Office przechowywanych w The National Archives w Kew, autor sięgnął do papierów Davida Lloyda George’a dostępnych w Parliamentary Archives w Londynie. Podjął kwerendę w Churchill College w Cambridge, studiując papiery Winstona Churchilla (ministra wojny w roku 1920) oraz akta Maurice'a Hankeya. W oksfordzkiej Bodleian Library skorzystał ze spuścizny Horace'a Rumbolda (pierwszego posła brytyjskiego w Warszawie). Odwiedził też The National Archives of Scotland, które przechowuje papiery Philipa Kerra, sekretarza premiera i właściwego twórcy projektu „linii Curzona”.

Źródłowe poszukiwania amerykańskie przyniosły przede wszystkim kwerendę papierów sekretarza stanu Bainbridge'a Colby'ego dostępne w Bibliotece Kongresu oraz kolekcji Bakhmieteva dostępnej wśród rękopisów biblioteki Uniwersytetu Columbia w Nowym Jorku. Ze źródeł proweniencji polskiej Nowak skorzystał z akt Instytutu Józefa Piłsudskiego w Nowym Jorku oraz papierów gen. Kazimierza Sosnkowskiego, przechowywanych w zbiorach Ossolineum we Wrocławiu ${ }^{2}$. Rosyjskie archiwalia przyniosła autorowi kwerenda w Państwowym Archiwum Historii Społeczno-Politycznej (RGASPI) oraz archiwum wojskowym (RGVIA) w Moskwie. Szczególnie korespondencja Wiktora Koppa z Władimirem Leninem pozostaje cenną pozycją wśród zespołów tej proweniencji.

Pozwoliłbym sobie dodać, iż dla „monografii definitywnej”, jaką jest książka Nowaka, byłoby może użyteczne sięgnąć jeszcze po akta francuskie, a mam na myśli archiwa Ministerstwa Spraw Zagranicznych w La Courneuve pod Paryżem - konkretnie zespoły z serii „Y - Internationale, Europe 1918-1940”: „Russie soviétique/URSS” oraz oczywiście „Pologne”. W książce, której poświęcone są niniejsze uwagi, polityka francuska przedstawiona została w oparciu o Documents diplomatiques français za rok 1920 wydane przed blisko już dziesięciu laty, ale oparte o rygorystyczną selekcję, co sprawiło, iż wiele istotnych dokumentów nie znalazło miejsca w tej publikacji ${ }^{3}$.

Polskie akta dyplomatyczne - za rok 1920 - przechowywane w zbiorach Instytutu Polskiego i Muzeum Sikorskiego w Londynie (zespół Ambasady w Londynie) oraz Archiwum Akt Nowych - autor zdecydował się pominąć, uznawszy najpewniej, iż nie jest to konieczne, skoro jego książka traktuje o polityce mocarstw Zachodu wobec Polski, a nie o polityce polskiej jako takiej.

2 Przekazane tam zostały przez żonę po śmierci generała (1969).

${ }^{3}$ Documents diplomatiques français (3 septembre - 31 décembre 1939), red. A. Kaspi, Bruxelles 2002. Moje uwagi recenzyjne - zob. M. Kornat, Francuskie dokumenty dyplomatyczne (3 września 1939 - 31 grudnia 1939 r.), DN 2004, 4, s. 231-244. 
Tytuł książki zawiera pojęcie „Zachodu”, ale w centrum rozważań, które otrzymaliśmy, dominuje Wielka Brytania. Narracja o polityce brytyjskiej wypełnia 80\% książki, co nie znaczy, że pominięto milczeniem poczynania takich mocarstw jak Francja czy Stany Zjednoczone. Rozdział: „Czy Piłsudski był narzędziem Paryża?” - traktuje o polityce francuskiej (s. 68-93), rozdział: „Bezsilność” mówi o polityce Stanów Zjednoczonych (s. 94-111). W jakiejś mierze ma to swoje uzasadnienie, gdyż o losach Polski latem 1920 r. decydowała Wielka Brytania. Za jej sprawą usiłowano narzucić narodowi polskiemu w Spa arbitralne rozstrzygnięcia, które sprawiłyby, że stałby się łupem rzuconym Sowietom. Premier francuski Alexandre Millerand Polski nie obronił. Można dodać, iż sam przez chwilę jakby nawet zwątpił w Polskę, kiedy armie sowieckie podeszły pod Warszawę.

Operacja appeasementu na rzecz Sowietów w roku 1920 była dziełem brytyjskim, na udaremnienie której nie zdołała się zdobyć Francja. Ta ostatnia miała trzy opcje: 1) usiłować porozumieć się z nowymi władcami Rosji; 2) walczyć o restytucję Rosji białej; 3) poszukiwać „sojusznika zastępczego”. Wybrano to drugie rozwiązanie, ale kiedy nadeszło polskie zwycięstwo nad Wisłą - i upadek białych (w końcu gen. Piotra Wrangla) - zdecydowano się na trzecie.

Struktura książki Nowaka pozostaje łatwa do streszczenia. Złożona jest z czterech części. Pierwsza z nich nosi tytuł: „Kłopot z polską niepodległością”, a jej celem pozostaje przypomnienie wielce problematycznej roli, jaką „w oczach Zachodu" pełniła odrodzona Polska - powracająca po ponad stuletniej przerwie na mapę Europy. Część druga: „Polski kryzys - krótki kurs”, daje streszczenie głównych kierunków rozwoju konfliktu polsko-sowieckiego w 1920 r. W trzeciej części, zatytułowanej „Jak pracuje mózg imperium?”, otrzymaliśmy niewątpliwie najcenniejszy, analityczny ogląd polityki brytyjskiej. Część czwartą swej pracy pomyślał autor jako „polskie aneksy i pytania”, a jej celem pozostaje m.in. polemika z rzecznikami tezy, iż Józef Piłsudski uratował bolszewizm jesienią 1919 r., gdyż nie poszedł na współpracę z „białymi”. Tam również znajdziemy obronę traktatu ryskiego z 18 marca $1921 \mathrm{r}$.

Spojrzenia na konflikt polsko-sowiecki w roku 1920 r. dałoby się ująć w postaci czterech podstawowych narracji:

1) Najpierw przypomnieć należy teorię o „imperializmie polskim”. We wspomnieniach Prawda o Traktacie Wersalskim, poświęconych „nowej Europie” po Wielkiej Wojnie, Lloyd George poświęcił Polsce wymowny komentarz:

Nikt nie sprawiał większego kłopotu niż Polacy. Polska była kiedyś największą potęgą militarną w Europie Środkowej - Prusy były wówczas słabiutkim księstwem i obecnie na wielkim terytorium, zamieszkałym przez szereg rozmaitych narodowości, mało było prowincji, których Polska nie mogłaby żądać jako swego dziedzictwa, z którego ją obrabowano. Upojona młodym winem wolności, dostarczonym przez Aliantów, wyobrażała sobie, że jest znów panią losów Europy Środkowej. [--] Samostanowienie jej nie odpowiadało. Pożądała Galicji, Ukrainy, Litwy i części Białorusi, gdzie głosowanie mieszkańców odrzuciłoby kategorycznie jej panowanie. Toteż polscy przywódcy odrzucili rychło zasadę prawa wszystkich narodów [do] wybierania sobie przynależności państwowej. Twierdzili, że owe różnorodne ludy należały 
do Polski na zasadzie zbrojnego podboju przez ich przodków. Tak jak normandzki baron, pytany o tytuł prawny do włości, wyciągał miecz z pochwy, Polska wskazywała na rdzewiejący od wieków w grobowcach miecz jej wojowniczych królów ${ }^{4}$.

Brytyjski premier narzekał, że w swej polityce faktów dokonanych Polska sporo osiągnęła, a przypisywał to przede wszystkim temu, że działania te odpowiadały interesom Francji i z tego powodu nie napotkała ona na skuteczny sprzeciw przywódców konferencji pokojowej. Sprawa polska znalazła też poparcie delegacji amerykańskiej, co Lloyd George - w oczywistym uproszczeniu tłumaczył osobistymi „wpływami” Ignacego Paderewskiego w Ameryce. W takiej perspektywie spojrzenia wojna polsko-sowiecka została więc wywołana przez Polaków i rozpoczęła się od ich agresji przeciw Sowietom.

2) Bardzo upowszechniona pozostaje do dzisiaj teza o de facto francuskim zwycięstwie pod Warszawą i gen. Maximie Weygandzie jako głównym jego architekcie. Teorię o jego decydującej roli najmocniej wypowiedział przywódca radykalnej prawicy francuskiej, twórca „Action Française” Charles Maurras, pisząc we wrześniu 1920 r., iż było to „zwycięstwo Weyganda” („victoire de Weygand”)5. Można przypuszczać, że był on pierwszym rzecznikiem tej tezy w opinii francuskiej. Maurras, jako pierwszy, jak się zdaje, nazwał Bitwę Warszawską „cudem nad Wisłą", co jest parafrazą sformułowania „cud nad Marną” (z września 1914 r.). Utrwalenie się mitu o Weygandzie jako „zbawcy Polski” nastąpiło zwłaszcza we francuskich kręgach wojskowych ${ }^{6}$. W liście do niego z 30 grudnia 1920 r. marszałek Ferdinand Foch nazwał go dowódcą, „który przesądził o całkowitym odwrocie armii bolszewickich i ocalił Polskę"7. Paul Painlevé jako minister wojny pisał, że Weygand „dał operacjom armii polskiej silny i oświecony impuls, co pozwoliło osiągnąć decydujące rozstrzygnięcia"8. Również marszałek Philippe Pétain twierdził, iż „swoim działaniem i radami Weygand wywarł wpływ decydujący, co spowodowało odwrót wspólnego wroga"'. Podważeniu mitu francuskiego generała nie pomogły zaprzeczenia samego generała, ani jego stwierdzenie, że było to „czysto polskie zwycięstwo" ${ }^{10}$, "wspaniałe zwycięstwo polskie” - „wiktoria polska”, on zaś nie jest „zbawcą Warszawy”"

${ }^{4}$ D. Lloyd George, Prawda o traktacie wersalskim, t. 1, Warszawa 1939 (oryg. ang. 1938), s. 277-278.

${ }^{5}$ Cyt. za P.S. Wandycz, General Weygand and the Battle of Warsaw of 1920, „Journal of Central European Affairs" 19, 1960, 4, s. 364.

${ }^{6}$ Także w historiografii francuskiej od dawna panuje ten mit i powraca w wystąpiee niach akademickich. Warto wspomnieć chociażby wystąpienie płk. Pierre’a Le Goyeta, La guerre polono-soviétique de 1919-1920. Colloque, red. C. Gervais, Paris 1975, s. 16-31.

7 Cyt. za: G. Raïssac, Un soldat dans la tourmente, Paris 1963, s. 38.

8 Ibidem, s. 38-39 (przyp. 1).

9 Ibidem, s. 39.

10 Wywiad gen. Weyganda w „L'Information” z 21 VIII $1920 \mathrm{r}$.

11 „magnifique victoire polonaise”, „une victoire polonaise”, „le sauver de Varsovie”, C. Smogorzewski, La Pologne restaurée, Paris 1927, s. 151-152. 
3) Oczywiście, nierzadko wojna polsko-sowiecka bywa sprowadzana do roli lokalnego konfliktu granicznego na peryferiach powojennej Europy. W takim ujęciu jawi się ona na podobieństwo wojny grecko-tureckiej 1921-1922. Traci w ten sposób rangę starcia, którego stawką było urządzenie powojennej Europy, a przede wszystkim tej jej części, która sytuuje się na wschód od Niemiec.

4) Kiedy mowa o odczytywaniu lekcji 1920 r. przez ludzi Zachodu, trzeba wspomnieć wreszcie o tych jego przedstawicielach, którzy w zwycięstwie polskim nad Wisłą upatrywali ocalenia cywilizacji Zachodu. Swoją książką o „osiemnastej decydującej bitwie w dziejach świata" pierwsze miejsce wśród rzeczników tej tezy zajął brytyjski ambasador w Berlinie Lord d'Abernon ${ }^{12}$. Premier Millerand wypowiedział się o Bitwie Warszawskiej bardzo podobnie. W $1932 \mathrm{r}$. powtórzył, że przyszłość cywilizacji zachodniej „rozstrzyga się nad brzegami Wisły”, a Polska uczestniczy w historii jako „żołnierz ludzkości” ${ }^{13}$. Oczywiście parafrazował tu słowa Jules’a Micheleta, wołającego osiemdziesiąt lat wcześniej z katedry w Collège de France, iż „cywilizację ratuje się nad Wisłą”.

Książką swą Nowak zaproponował odczytanie lekcji wojny polsko-sowieckiej jeszcze inaczej. Dostrzegł w niej nieurzeczywistnione doświadczanie usiłowań zaspokojenia „nowej” Rosji przez Zachód - kosztem Polski, co jednak Polacy zdołali udaremnić za sprawą swojego nieoczekiwanego zwycięstwa nad Wisłą w sierpniu $1920 \mathrm{r}$.

Nie jest to jednak książka o polityce polskiej, tylko brytyjskiej przede wszystkim, która stała się siłą sprawczą próby ugody z rządem Sowietów - na gruzach naszej odrodzonej ojczyzny. Wielowątkowe studium ma w swym centrum część trzecią zatytułowaną: „Jak pracuje mózg imperium?” (s. 207-445), czyli właściwie osobne studium procesu kreowania polityki brytyjskiej w latach 1919-1920 wobec Europy Wschodniej. Autor odsłania role i poglądy lorda Arthura Balfoura, Lewisa Namiera, sekretarzy premiera Lloyda George'a - Philipa Kerra i Maurice’a Hankeya, posła w Warszawie Horace'a Rumbolda i „bezsilnych ministrów” spraw zagranicznych i wojny: George'a Curzona i Winstona Churchilla.

Pojęcie appeasementu, czyli „zaspokajanie”, jest stosowane głównie (a nawet wyłącznie) do polityki mocarstw zachodnich wobec Niemiec pod koniec lat trzydziestych ${ }^{14}$. W takim kontekście zasługuje na potępienie. Tak mówi obowiązujący

12 Lord d'Abernon, The Eighteenth Decisive Battle of the World. Warsaw, 1920, London 1931. Polski przekład: Osiemnasta decydujaca bitwa w dziejach świata. Pod Warszawa 1920 roku, przedm. min. A. Zaleski, Warszawa 1932. Książka brytyjskiego dyplomaty to wyciąg z jego dziennika pisanego w lipcu i sierpniu 1920 r. na bieżąco, co dodaje jej rangi źródła. Cztery ostatnie rozdziały autor dopisał ex post jako komentarz z perspektywy czasu.

13 „comme soldat de l'humanité”, A. Millerand, Au sécours de la Pologne, „Revue de France" 12, 1932, s. 578.

14 Panuje consensus omnium co do tego, iż impulsem decydującym do tej polityki stała się listopadowa podróż Lorda Halifaxa do Hitlera w 1937 r. Niektórzy historycy utrzymują, iż lata 1933-1937 stanowiły fazę preappeasementu, a zainaugurowała ją niezrealizowana koncepcja Paktu czterech mocarstw. 
w podręcznikach akademickich dyskurs historiograficzny. Ale był też appeasement wobec Rosji. Jego wymowny triumf ujawnił koniec II wojny światowej. Jednak to rok 1920 przyniósł jego pierwszą odsłonę. I tak oto konferencja w Spa jawi się prawdziwą prefiguracją Jałty. Oczywiście, kiedy myślimy o appeasemencie, mamy w pamięci rok 1938. Czechosłowacja stała się jego ofiarą. Mechanizm jest jednak ten sam. Uchwały konferencji w Spa mają u podstaw tę samą motywację co plan brytyjsko-francuski z 21 września, doradzający Czechosłowacji cesję terytorialną Sudetów. Podobieństwo to objawia się w idei cesji terytorialnej ze strony słabszego partnera na rzecz agresora, aby okupić pokój. Zastosowanie przez autora Pierwszej zdrady Zachodu pojęcia appeasementu do realiów roku 1920 ma w moim przekonaniu swój sens.

Krytyczny odbiorca tez Nowaka protestować może przeciw sformułowaniu o „zdradzie” Zachodu. Czy nie jest ono przesadne? Czy nadmiernie nie upolitycznia dyskusji nad dziejowym doświadczeniem wojny polsko-sowieckiej? Autor ma argument, aby się bronić. Przypomina, iż podstawą jego twierdzenia pozostają uchwały Rady Najwyższej mocarstw sprzymierzonych podjęte w Spa w lipcu 1920 r. Powzięto tam decyzję, że w zamiana za zgodę na okrojenie od wschodu (i ustępstwa na zachodzie: Śląsk Cieszyński, status Gdańska itd.) Polska otrzyma ich pomoc, co nie nastąpiło. Dodam od siebie, iż nawet stylizacja umowy ze Spa podobna jest do monachijskich uchwał osiemnaście lat później. Nie zapominajmy też i o tym, że poprzez samo zaproszenie do Paryża na konferencję pokojową Polskę włączono do koalicji zwycięskiej, co dawało określone gwarancje. Ale konstatując niewypełnienie zobowiązań, zauważyć jeszcze trzeba, iż sama obecność dwóch misji międzysojuszniczych w Polsce (wojskowej z gen. Weygandem na czele oraz politycznej, kierowanej przez ambasadorów Jules'a Jusseranda i Lorda d'Abernona) miała określone znaczenie dla polskiego morale w rozstrzygających chwilach Bitwy o Warszawę.

$\mathrm{Na}$ pewno nasuwa się problem definicji appeasementu. Zasadnicze skojarzenia związane $\mathrm{z}$ tym pojęciem prowadzą do wniosku, iż u jego podstaw tkwi naruszenie zobowiązań określonych normami prawa międzynarodowego. W roku 1938 naruszyła je Francja wobec Czechosłowacji. W roku 1920 mocarstwa Zachodu takich na rzecz Polski nie zaciągnęły. Ale - pamiętajmy - państwo polskie zaproszono na paryską konferencję pokojową, uznając tym samym jego prawa wynikające z przynależności do zwycięskiej koalicji.

Właśnie rok 1920 wymownie unaocznił mechanizm zapłaty agresorowi na koszt państwa trzeciego (które z racji swego położenia geopolitycznego stało się jego ofiarą). I taka jest istota appeasementu - prawdziwie ponadczasowa, nieobca i naszym czasom. Brytyjska nota do rządu Sowietów z 10 sierpnia 1920 r. jest aktem zaspokajania agresora. Okrojenie, degradacja, jednostronne rozbrojenie, wydanie na łup Rosji Sowieckiej - to los, jaki gotowano Polsce. Dopowiedzmy za Nowakiem, iż słowo appeasement pojawiło się w jednym $\mathrm{z}$ dokumentów brytyjskich już z lata 1920 (s. 390), a w języku brytyjskiej myśli politycznej zaistniało dużo wcześniej. Istotą appeasementu nie jest tylko idea dysponowania interesami państw trzecich $-\mathrm{w}$ imię ugody między mocarstwami. Jest nią również koncepcja 
hierarchii państw w stosunkach międzynarodowych. Odmówienie prawa do kształtowania pokoju narodom nienależącym do kategorii wielkich mocarstw pozostaje fundamentem tej logiki. Prawdziwą istotą filozofii appeasementu pozostaje wyniosłe przekonanie, iż „z Zachodu widać lepiej jak urządzić Wschód” europejski (s. 225). „O tym, czy w Europie Wschodniej ma prawo istnieć jakiś kraj, jakaś wspólnota polityczna, a także o tym, jakie mogą być jej granice, decyduje przede wszystkim korzyść dla Europy Zachodniej, widziana przez pryzmat interesu brytyjskiego" - stwierdza Nowak (s. 223).

Nie tylko więc motyw równowagi sił tkwił w centrum tej koncepcji pokoju międzynarodowego, jaką był appeasement z 1920 r., lecz przede wszystkim idea zaspokojenia roszczeń agresora.

Co interesujące, barbarzyńskość reżimu sowieckiego nie okazała się przeszkodą dla zastosowania appeasementu. Musi to zastanawiać. Nie może nie być ostrzeżeniem - prawdziwie ponadczasowym. „Ucywilizowanie” Sowietów jako barbarzyńców, „przez handel” przyświecało Lloydowi George’owi (s. 352). Ucywilizowanie Rosji na drodze kontrolowanej ekspansji, na którą się jej pozwoli, miało dać trwały pokój (s. 441). Zabrakło zrozumienia siły totalitarnej ideologii - tkwiącej u podstaw bolszewickiego reżimu. Brak zdrowej wyobraźni co do rzeczywistego oblicza sowieckiej tyranii w 1920 r. pozostaje wyraźny. Ale to się powtórzy szesnaście i osiemnaście lat później, kiedy zabraknie tej wyobraźni w podejściu do Hitlera i jego państwa (w latach 1936 i 1938).

Analizując politykę Imperium Brytyjskiego, Nowak słusznie podnosi, iż była ona osobistym dziełem Lloyda George'a. On jako premier ją kreował. Curzon i Churchill - czyli ministrowie spraw zagranicznych i wojny, byli prawdziwie bezsilni. Co więcej, pozostawali w sporze o politykę wobec Europy Wschodniej zamiast się wzajemnie wspierać (s. 338).

Kiedy mowa o politykach brytyjskich, wspomnieć wypada tytułem komentarza, iż minister wojny Churchill artykułem The Poison Peril from the East, drukowanym 28 lipca 1920 r. na łamach londyńskiego pisma „Evening News”, podkreślał, że niepodległe państwo polskie jest konieczne dla Europy. Jeśli zniknie z jej mapy - będzie to zagrożeniem dla mocarstw zachodnich. W tym samym artykule przyszły premier trafnie zauważył, że pokój z Sowietami to tylko „inna forma wojny". Ten przenikliwy sąd Churchilla pozostał wszakże odosobniony. Prosowiecką siłą stała się Partia Pracy, Lloyd George zaś prowadził arbitralnie kreowaną politykę zagraniczną, której przyświecała wizja ugody z nową Rosją.

Nowak słusznie zwraca się polemicznie przeciw tezom historiografii zachodniej, głoszącym, że w swej polityce wschodniej Piłsudski był narzędziem Francji. Opinię taką wypowiedział znany prosowiecki historyk kanadyjski Michael Jabara Carley (s. 92). W rzeczywistości cała polityka polskiego Naczelnika Państwa była zaprzeczeniem klientalnej zależności.

Kiedy mowa o realiach stosunków międzynarodowych w Europie po Wielkiej Wojnie, trzeba wspomnieć, iż wytworzył się język-dyskurs o samostanowieniu narodów jako podstawowej zasadzie organizującej nowy ład. Ale imperia nie musiały go honorować. Idea samostanowienia działała za Polską, ale też przeciw 
Polsce. Consensus omnium kształtował się raczej wokół tezy o „Polsce etnograficznej”. Ta wizja stała się kluczem dla zrozumienia brytyjskiej wizji Polski i jej roli w stosunkach. Wyrosła niewątpliwie jako koncepcja zrodzona w niemałej części z niezrozumienia realiów geografii politycznej Europy Środkowo-Wschodniej. Warto zauważyć, że w kluczowym momencie wojny polsko-sowieckiej dziennik „Times” pisał, iż gdyby Polska zaakceptowała status państwa „w granicach etnograficznych", przestałaby wadzić komukolwiek i mogła żyć w spokoju. Rzecz jasna, idea "granic etnograficznych" Polski stanowiła zasadniczy punkt widzenia brytyjskich czynników politycznych. Innymi słowy, państwo polskie jest w interesie Europy i ma prawo do istnienia, ale w granicach tylko „etnograficznych”.

U podstaw appeasementu z $1920 \mathrm{r}$. tkwiła idea korektury świeżo kreowanego ładu wersalskiego jako systemu na dalszą metę nie do utrzymania.

Polska swoją polityką nie zadowoliła się wyznaczonym jej miejscem małego państewka. "Chory imperializm” polski prowadzi logicznie do sojuszu niemiecko-rosyjskiego - dowodził Lewis Namier (s. 255), a więc urzędnik Political Intelligence Department w Foreign Office. Argumentacja jego powtarzała to, co powiedział Lord Balfour jesienią 1916 r., kiedy w brytyjskim rządzie toczyły się narady wokół przyszłego ładu Europy.

Odrodzona Polska nie miała możliwości określania priorytetów politycznych mocarstw zachodnich. Tak było w roku 1920. Tak będzie i w roku 1939.

Czy jednak z tego wyciągać mamy wniosek, iż dobrowolna zgoda na uprzedmiotowienie jest jedynym wyjściem z sytuacji? Nie. Logika uległości właściwie nigdy nie owocowała korzyściami. W uwagach Nowaka o polityce i dyplomacji polskiej w 1920 r. (s. 397) rzuca się w oczy jego konstatacja, iż premier Władysław Grabski w Spa zachowywał się poniżająco. Podpisał zgodę na wszystkie żądania Lloyda George'a. Autor Pierwszej zdrady Zachodu porównuje to postępowanie do zachowania prezydenta Czecho-Słowacji Emila Háchy dziewiętnaście lat później, czyli w marcu 1939 r. przed obliczem Hitlera.

W końcowych fragmentach książki Nowak zatrzymuje się nad powieścią Józefa Mackiewicza Lewa wolna (1965). Pisarz ów - jak wiadomo - dowodzi, iż Piłsudski nie skorzystał ze sposobności, aby zdławić bolszewizm, dochodząc do porozumienia z siłami „białych” jesienią 1919 r. Nowak analizuje tezy powieści Mackiewicza. Obecnie do tych poglądów nawiązał publicysta Piotr Zychowicz (książka Pakt Piłsudski - Lenin, czyli jak Polacy uratowali bolszewizm $i$ zmarnowali szansę na budowę imperium, Warszawa 2015), który w sposób skrajnie prymitywny i nie bez dużej naiwności kreuje pseudohistoryczną narrację o pokoju ryskim jako „zdradzie”, gdyż Polacy oddali Sowietom pół swego kraju (Rzeczypospolitej), zostawiając 1,5 mln ludności polskiej na łup czerezwyczajki (WCzK). Oskarżenia te próbują uderzyć w Józefa Piłsudskiego i podważyć jego reputację jako męża stanu.

Nowak wskazuje przede wszystkim na układ sił militarnych. Polskie siły zbrojne liczyły 600 tys. żołnierzy. Siły „białej” Rosji w szczytowej fazie ich rozwoju osiągnęły ponad 500 tys. Naprzeciw tym liczbom stało ponad trzy i pół miliona żołnierzy wojsk bolszewickich (s. 465). 
To prawda, że Piłsudski nie pomógł „białym”, choć pragnęli tego przede wszystkim Francuzi. Trudno popuszczać wodze fantazji i spekulować, „co by było gdyby” postąpił inaczej. Pamiętajmy o nieubłaganym żądaniu „białych”, by zamknąć Polskę w jej granicach Królestwa Kongresowego. W 1936 r. Stanisław Grabski wyznał w rozmowie z Mieczysławem Pruszyńskim, podkreślając, iż „tylko od Rosji bolszewickiej mogliśmy wywalczyć uzyskane granice”15. Poza tym jeszcze jedno jest bezsporne. Obudowanie Rosji „białej” byłoby dla Polski rozwiązaniem nie do pozazdroszczenia. Nie przyniosłoby, być może, natychmiastowej wojny polsko-rosyjskiej, gdyż Rosjanie nie mieliby dostatecznych sił, by uderzyć na Polskę. Ale ta właśnie odrodzona, „biała” Rosja stałaby się aliantem zwycięskiej Francji. Dla Polski nie byłoby miejsca w europejskiej konfiguracji sił. Żaden rząd Rosji „białej” nie zgodziłby się na granice, które ustalono w rokowaniach ryskich między delegacjami Polski i rządu Sowietów.

Ocena pokoju ryskiego jest u Nowaka spokojna, wyważona, a przede wszystkim kreślona z przekonaniem, że nie było alternatywy.

Wszystkie w zasadzie źródła polskie z przełomu 1920 i 1921 r. wskazują, że po stronie polskiej zapanowało zgodne przekonanie, iż zawarcie pokoju z sowiecką Rosją stanowi absolutną konieczność z racji wyczerpania kraju w dotychczasowej wojnie oraz z powodu potrzeby skupienia wszystkich sił, aby wywalczyć korzystne rozwiązanie w sprawie przyszłości Górnego Śląska. Zachodziła konieczność zawarcia pokoju tak z powodów militarnych, jak i gospodarczych. Nie było już miejsca na rozważania wokół politycznych planów na wschodzie. Jedyne rozwiązanie, jakie pozostało, to pokojowo uzyskać „spełnienie minimalnych żądań”.

Ostatnie miesiące wojny wykazały, że skarb polski żadną miarą sam bez pomocy aliantów dalszej wojny wytrzymać nie może. Zarówno stronnictwa polityczne, jak i całe w ogóle społeczeństwo faktycznie spragnione jest pokoju. Wojsko nasze aczkolwiek zdolne do chwilowego wysiłku, nie może być uważane za armię, z którą by można prowadzić trudne i na daleką metę obliczone operacje wojenne. Koniecznie potrzebny jest pokój dla ekonomicznego podniesienia się i skonsolidowania państwa, dla utworzenia rządu istotnie zdolnego do kierowania nawą państwową, wreszcie organizacji państwowej i urzędów zdolnych do celowej administracji. Dalsze prowadzenie wojny byłoby zatem nonsensem, jeżeli jest możliwe uzyskać pokojowo minimalne żądania narodu polskiego

- pisał w jednej z instrukcji dla polskich placówek dyplomatycznych minister spraw zagranicznych Eustachy Sapieha.

W obronie traktatu ryskiego Nowak nawiązuje do swoich wcześniejszych prac i interpretacji. Afirmatywnie wyzyskuje ustalenia Jerzego Borzęckiego, którego monografia The Soviet-Polish Peace of 1921 and the Creation of Interwar Europe (New Haven 2008, wydanie polskie: Pokój ryski 1921 r. i kształtowanie się międzywojennej Europy Wschodniej Warszawa 2012) przyniosła ostatni (jak dotychczas) głos historiografii na temat tej regulacji terytorialnej.

15 M. Pruszyński, Tamci, Warszawa 1992, s. 25. 
Jest prawdą, iż Piłsudski, jak pokazuje to Diariusz 1919-1935 Kazimierza Świtalskiego - uważał na przełomie 1920/1921 r., iż wojna polsko-sowiecka będzie nieuchronnie wznowiona, ale nie brał w rachubę nowej ofensywy polskiej. W lutym 1921 r. Naczelnik Państwa stwierdził, iż gdyby to nastąpiło, bolszewicy „stracą Mińsk, dojdziemy do Berezyny, choćby do Dniepru, to wszystko już było"16. Dalszy marsz polskiej armii na wschód zdawał się pomysłem nieracjonalnym. $\mathrm{Na}$ dalszą wojnę brak było też przyzwolenia społeczeństwa polskiego - i to wydaje się najważniejsze. Można sobie wyobrazić trzy scenariusze: 1) kontynuowanie wojny bez nadziei na powodzenie i z wielkim ryzykiem; 2) podpisanie kompromisowego pokoju; 3) niezawieranie pokoju w warunkach zakończenia działań militarnych. To ostatnie rozwiązanie prowadziło wszakże do przedłużenia stanu „ni pokój, ni wojna”. Nie było w tej sytuacji żadnych szans stabilizacji położenia państwa i pozyskania sojuszników. Państwo niemające granic, nie może być wiarygodnym podmiotem stosunków międzynarodowych. Można zauważyć, iż gdyby stan „ni wojna, ni pokój” przedłużył się do 1922 r., kiedy przyszło porozumienie sowiecko-niemieckie w Rapallo, Sowieci mogliby w ogóle nie być zainteresowani jakimkolwiek porozumieniem pokojowym. Nowak słusznie konstatuje, iż pokonana Rosja była w kryzysie, ale Polska znajdywała się w niewiele „lepszej sytuacji” (s. 466).

Nowak przyznaje, iż traktat ryski nie spełnił oczekiwań wszystkich narodów Europy Wschodniej (s. 512) - nad prawami narodów ukraińskiego i białoruskiego przeszedł przecież do porządku dziennego. Jednak jako regulacja pokojowa przyniósł unikalne doświadczenie z punktu widzenia stosunków międzynarodowych. Łamał bowiem zasadę, że „tylko wielkie mocarstwa mogą rozstrzygać o obliczu stosunków międzynarodowych" (s. 512). Pokój ten ustanowił geopolityczną „przegrodę” między Niemcami a Rosją, blokującą terytorialny dostęp tej ostatniej do Niemiec, jak to ujął Stalin już jesienią $1918 \mathrm{r}$.

Oczywiście rozmaite pytania wokół rokowań ryskich muszą pozostać w mocy. Na miejscu jest choćby pytanie o przebieg sporów wewnątrz delegacji polskiej. Jak ujawnił jej sekretarz generalny Aleksander Ładoś, w głosowaniu, a nie na podstawie konsensusu, ustalono, aby nie żądać Mińska. Zbieżne z tą relacją jest stwierdzenie Jana Dąbskiego w jego wspomnieniach ${ }^{17}$. W tych warunkach obóz Piłsudskiego konsekwentnie wysuwał tezę, iż podczas rokowań w Rydze Stanisław Grabski - mając zasadniczy wpływ na stanowisko delegacji polskiej w rokowaniach pokojowych - kierował się swoistym „minimalizmem” politycznym i opowiedział się za umiarkowanymi postulatami terytorialnymi na wschodzie. Stanowisko to narzucił delegacji polskiej. Koncepcja ta miała swoje uzasadnienie w tym, że narodowi demokraci pragnęli widzieć w państwie polskim tylko tyle mniejszości narodowych, ile da się spolonizować w przyszłości.

16 Notatka K. Świtalskiego z rozmowy z Piłsudskim z 21 II 1921 r., K. Świtalski, Diariusz 1919-1935, oprac. A. Garlicki, R. Świętek, Warszawa 1992, s. 75.

17 J. Dąbski, Pokój ryski. Wspomnienia, pertraktacje, tajne układy z Joffem, listy, Warszawa 1931, s. 111. 
Do tej sprawy powracano jeszcze w historiografii i we wspomnieniach świadków wydarzeń bardzo wiele razy. Zagadnienia tego nie będziemy tu rozpatrywać, bowiem nie ono jest tematem niniejszych refleksji. Poprzestać wypada tylko na przypomnieniu, że cała kontrowersja wzięła się stąd, iż dwaj uczestnicy rokowań ryskich, których w żadnym wypadku nie można uznać za przynależących do obozu Piłsudskiego, dawali do zrozumienia, że możliwe było wynegocjowanie takiego rozwiązania terytorialnego (bez wznawiania wojny), które pozwoliłoby ocalić „,ideę federacyjną” w odniesieniu do Białorusi. Najpierw uczynił to Dąbski w swych wspomnieniach, wydanych na krótko przed śmiercią. Napisał, że Sowieci byli bezwzględnie przeciw możliwościom wszelkich koncesji w sprawie Ukrainy, bowiem: „Kwestia Ukrainy była i jest dla Rosji zagadnieniem być albo nie być. [--] Ustępliwszymi byliby bolszewicy rosyjscy w sprawie oddania pod wpływy polskie całej Białej Rusi, ale próby postawienia tej sprawy w Rydze natrafiały na zdecydowany opór ze strony polskiej"18. Ładoś poszedł w tym samym kierunku, przypominając, iż koncepcja Grabskiego zwyciężyła zanim przystąpiono do rokowań - została przegłosowana po obradach delegacji polskiej. Dodać należy, iż krytycy linii negocjacyjnej delegacji polskiej w Rydze powoływali się na jeszcze inny argument - na sowieckie oferty pokojowe ze stycznia 1920 r. Wówczas to rząd Rosji Sowieckiej oferował Polsce pokój na zasadzie uznania wzajemnego stanu posiadania, tak jak on się przedstawiał. To zaś oznaczało, że strona polska otrzymałaby granicę ok. 150 kilometrów na wschód od późniejszej „granicy ryskiej”. Skoro zatem Sowieci przed konfrontacją wojenną skłonni byli do tak znaczących ustępstw, to po klęsce w Bitwie Warszawskiej musiały powstać szanse uzyskania przynajmniej tego samego - taka była od początku myśl przewodnia krytyków pokoju ryskiego.

Jedną z końcowych refleksji Nowaka jest pytanie wielkiej wagi: „Czy trwały pokój, to wielkie dobro, może zagwarantować tylko siła, jaką dysponują największe mocarstwa?” (s. 513). Czy w tej sprawie liczą się również „aspiracje i poczucie sprawiedliwości" tych, których on dotyczy? Pozostawia je Autor Pierwszej zdrady Zachodu bez odpowiedzi. Skłania się ku konstatacji, iż historyk może tylko gromadzić argumenty do odpowiedzi na nie.

Książka Nowaka przynosi bardzo wiele cennych refleksji. Jest dobrze udokumentowana. Chciałoby się jednak zgłosić parę uwag na marginesie - niektóre postulatywnie, inne jako argument w dyskusji.

Może wskazany byłby osobny rozdział książki o stanowisku Włoch. Owszem, poglądy włoskich mężów stanu (Francesca Nittiego czy Carla Sforzy) na sprawy polskie nie są nieznane. Italia należała jednak do ścisłego grona trzech mocarstw Ententy i chociaż nie była w stanie przeprowadzić swego zdania wbrew Francji czy Wielkiej Brytanii, to jednak podobne do brytyjskich zapatrywania Nittiego na sprawy polskiej znacznie ułatwiały Lloydowi George’owi realizację jego planu wobec Polski.

18 Ibidem. 
Kiedy mowa o tym, że rząd USA uznawał prawo do niezawisłości i oderwania się od Rosji Polski (Kongresowej oczywiście) i Finlandii (s. 499) - warto dodać, że prawo takie przyznawano w Waszyngtonie również Armenii, której sprawa z powodu tureckiego ludobójstwa (1915) zyskała duże poparcie amerykańskiej opinii publicznej.

Nie jestem przekonany, czy rzeczywiście „wielki projekt Wilsona” zakładał „przekreślenie polityki zagranicznej poszczególnych państw”, z tym że „pierwsze z niej miały zrezygnować państwa mniejsze" (s. 44). Stwierdzenie to wydaje się zbyt daleko idące, bo przecież system Ligi Narodów - mimo wszystko daleki był od pozbawienia jej członków suwerenności państwowej.

Wyniosła ignorancja brytyjskich mężów stanu i ekspertów w podejściu do spraw Europy Wschodniej pozostaje faktem i słusznie Autor omawianej książki ją akcentuje. Ale warto może z naciskiem wskazać też i na obiektywne trudności w urządzaniu tego wielce skomplikowanego obszaru postimperialnego, tak pod względem stosunków narodowościowych, jak i powikłań politycznych. Trudności te istniały niezależnie od zapatrywań i kompetencji zachodnich przywódców i architektów wersalskiego pokoju.

Słuszna jest w moim przekonaniu obronna argumentacja Autora w związku ze sporami o traktat ryski. Jednak trudno się oprzeć refleksji, iż sytuacja, kiedy pokój negocjuje delegacja posłów sejmowych bez jakiejkolwiek kontroli ze strony ministra spraw zagranicznych Eustachego Sapiehy, pozostaje czymś co najmniej nienormalnym.

Można by dodać jeszcze, iż pojęcie appeasementu - skompromitowane w naszych oczach za sprawą Monachium (1938), nie miało w języku angielskim oraz brytyjskiej tradycji politycznej negatywnej konotacji. Było raczej synonimem polityki wybitnie pokojowej, opartej na przesłankach szukania ugody i kompromisu. Kiedy więc pojęcie to spotykamy w dokumentach Foreign Office, trzeba pamiętać o tej dychotomii w jego percepcji.

Summa summarum, nasuwa się podstawowy wniosek. Polska udaremniła pierwsze zastosowanie appeasementu swoim kosztem. Ale polskie zwycięstwo wbrew wszystkim założeniom zrodziło „resentyment” u elit anglosaskiego świata, skutkujący tym, by poddawać bezpardonowej krytyce ład wersalski, a już zwłaszcza wersalsko-ryski (s. 512). I krytyka tego ładu jest do dziś bardzo silna, co pokazały nam na świeżo obchody stulecia wybuchu I wojny światowej z roku 2014.

Zgadzając się tym stwierdzeniem, dodałbym jeszcze - mówiąc wprost - iż w XX w. w Europie „Międzymorza” tylko dwóm narodom udało się to osiągnąć i obronić niepodległość: Polakom w roku 1920 i Finom w 1939. Na pytanie, czy pojedynczy naród - nie dysponując potencjałem mocarstwa - może obalić zaoczny wyrok obcych potęg - odpowiedź jest twierdząca. Muszą temu jednak towarzyszyć szczególne okoliczności „dodatkowe”. Zdarzają się one nader rzadko. W przypadku Polski był to olśniewający plan zwycięskiej kontrofensywy w bitwie nad Wisłą. W przypadku Finlandii - potężna Linia Mannerheima, sroga zima 1939/1940 i publicznie zadeklarowana oferta pomocy ze strony Francji i Wielkiej Brytanii, która jednak przestraszyła Stalina. 
Rozpatrując rozmaite momenty historyczne, Autor Pierwszej zdrady Zachodu analizuje możliwe alternatywy - jak choćby jesień 1919 r., kiedy Piłsudski zdecydował się nie wspierać sił gen. Antona Denikina - ale powtarza z naciskiem: „Historia nie jest nauką eksperymentalną, w której moglibyśmy sprawdzić różne jej warianty, powtarzając jej doświadczenie przy zmianie jednego czynnika”(s. 464).

Nowak słusznie, w moim przekonaniu, używa pojęciaład wersalsko-ryski, użyte po raz pierwszy - jak się zdaje - przez Wiesława Balceraka ${ }^{19}$. Wspomnieć należy, iż stosował je już wcześniej w swych licznych publikacjach. Znaczenie polsko-sowieckiego traktatu było doniosłe. Pokój ryski był podstawowym komponentem ładu pokojowego na kontynencie europejskim. Przyniósł konieczne dopełnienie ładu wersalskiego, albowiem w Wersalu pozostawiono wschodnią część Europy w swoistym stanie vacatio legis. W marcu $1921 \mathrm{r}$. ustanowiony został ład terytorialny dla Europy Wschodniej, chociaż tylko na nieco ponad osiemnaście lat.

Książka Nowaka pozostaje istotnym spojrzeniem na kształtowanie się poglądów elit politycznych Zachodu na temat Polski, a ściślej - jej roli w stosunkach międzynarodowych. Czy była zarzewiem niepokojów, czy „natchnieniem dla świata"? - jak później, w 1941 r. powie Franklin D. Roosevelt. Rok 1920 był pierwszym akordem długiego procesu akomodacji nowej, powracającej na dziejową scenę Polski do realiów międzynarodowych. Proces ten trwał przez cały okres jej niezawisłości.

Wśród polityków międzywojennej Europy dominowało przekonanie o niepewnej przyszłości odbudowanej Polski. Najmocniej wątpiono w to, że zdoła być barierą między Niemcami a Rosją. Wątpiono też w jej konsolidację wewnętrzną. Przewidując, że Polska nie będzie mogła być skuteczną barierą, Lord Balfour opowiadał się przeciwko jej niepodległości, argumentując w ten sposób w swoim memorandum: „The Peace Settlement in Europe” z końca 1916 r. ${ }^{20}$ Ekonomiczne możliwości samodzielnej egzystencji państwa polskiego niezmiernie nisko ocenił John Maynard Keynes, który w ogóle uznał cały system wersalski za strategiczny i kosztowny błąd ${ }^{21}$. Większych szans nie dawał Polsce znany pisarz polityczny francuskiej prawicy nacjonalistycznej, Jacques Bainville, który argumentował, że Polska nigdy nie zastąpi Rosji jako wschodni sojusznik zwycięskiej Francji ${ }^{22}$. „Bariera, którą Polska chce wznieść między Niemcami i Rosją to nonsens, który nie przetrwa" - pisał włoski polityk lewicowy, $\mathrm{Nitti}^{23}$.

19 W. Balcerak, Na drodze do wojny. Europa Środkowo-Wschodnia wobec agresji niemieckiej i sowieckiej, w: Od Wersalu do Poczdamu. Sytuacja międzynarodowa Europy Środkowo-Wschodniej 1918-1945, red. A. Koryn, Warszawa 1996, s. 106-116. Nowak wypowiadał się wielokrotnie z podobnym przekonaniem.

${ }^{20}$ W. Sukiennicki, Balfour a Polska, „Zeszyty Historyczne” 1970, 17, s. 39-55.

${ }^{21}$ J.M. Keynes, The Economic Consequences of the Peace, London 1919.

${ }^{22}$ J. Bainville, Les conséquences politiques de la paix, Paris 1920, s. 172-173.

23 „La barrière que la Pologne veut élever entre l'Allemagne et la Russie est une absurdité qui ne durera pas", F. Nitti, L'Europe sans paix, Paris 1923, s. 335. 
Lord Balfour rzucił pogardliwe stwierdzenie, iż „nikt nie wie jaka jest polityka polska” („nobody knows what is Poland's policy”), które później głośno komentowano w prasie europejskiej, minister spraw zagranicznych Aleksander Skrzyński zaś publicznie polemizował z tym stwierdzeniem ${ }^{24}$. Granice państwa polskiego były uważane za nienadające się do obrony.

Doświadczenie „polityki równowagi” Józefa Piłsudskiego i ministra Józefa Becka, będącej dramatyczną obroną niezawisłości Polski w skrajnie niesprzyjających uwarunkowaniach zewnętrznych, spotkało się z wrogością nie tylko Moskwy czy nieufnością Berlina, ale nade wszystko z niezrozumieniem i bezpodstawnymi oskarżeniami płynącymi ze stolic mocarstw zachodnich - Francji i Wielkiej Brytanii, a więc stamtąd, skąd winno było płynąć raczej wsparcie. Wielokrotnie stawiałem sobie pytanie, co tkwiło u podłoża tych zjawisk i odpowiedź jest jednoznaczna: otóż polityka ta nie pasowała do koncepcji appeasementu kiedy polityka appeasementu wkroczyła w decydującą fazę i zaowocowała konferencją monachijską. A więc zły klimat wokół Polski powstaje wtedy, kiedy usiłuje ona bronić swych interesów „na własną rękę" i kiedy trzeba przejść do porządku nad jej interesami. Tak było w dobie appeasementu i II wojny światowej. To wówczas właśnie odradzał się na Zachodzie groźny stereotyp Polski. Zły odbiór ,polityki równowagi" brał się przede wszystkim stąd, że polityka ta nie pasowała do koncepcji obrony pokoju na drodze ustępstw wobec Niemiec, a koncepcje takie w Londynie i Paryżu w drugiej połowie lat trzydziestych przecież zwyciężały.

Ale nie ma w historii naszego narodu tradycji kapitulacji - jest tradycja sprzeciwu wobec dyktatu możnych tego świata, a rok 1939 i polskie "nie” powiedziane Hitlerowi stanowi tu przykład wymowny. Historię Europy XX stulecia pisano po II wojnie światowej bez znaczącego udziału nauki polskiej. Historiografia polska w kraju, poddana ideologicznemu ciśnieniu, w niewielkim stopniu uczestniczyła w kształtowaniu poglądów historiografii światowej na sprawę genezy i przebiegu II wojny światowej. Dzisiaj jest naszym obowiązkiem pamiętać o tym, że wojna zaczęła się od Polski, że polskie "nie” powiedziane Hitlerowi przyczyniło się do upadku „polityki appeasementu”, że gdyby rząd polski przyjął żądania niemieckie, historia Europy potoczyłaby się inaczej. Ciąży na nas dzisiaj - na historykach polskich - obowiązek przypominania tych prawd zasadniczych. "Jesteśmy to winni wielkości ideału narodowego i wielkości ofiar złożonych przez poprzednie pokolenia" - jak pisał czterdzieści lat temu historyk polski Henryk Wereszycki ${ }^{25}$.

W konkluzji niech nam będzie wolno raz jeszcze odwołać się do słów Edwarda Raczyńskiego, dyplomaty i świadka wieku XX, bowiem trudno o bardziej trafne i dobitne podsumowanie problemu, który rozpatrywaliśmy. Walka o poparcie państw obcych dla interesów własnego państwa jest i zawsze będzie wielkim zadaniem każdej dyplomacji. „Ale jedną prawdę naród nasz, a więc moje

${ }^{24}$ A. Skrzyński, Poland and Peace, London 1924. Zob. także A. Zaleski, Przemowy i deklaracje, t. 1, Warszawa 1929, s. 56-57.

${ }^{25}$ H. Wereszycki, Niewygasła przeszłość. Refleksje i polemiki, Kraków 1987, s. 415. 
pokolenie i późniejsze pokolenia stwierdzić mogły na podstawie naszych przeżyć, że naród nasz nie może oczekiwać bezinteresownej i skutecznej pomocy z zewnątrz, która by zadecydowała o jego losie, że polegać musi przede wszystkim na własnych siłach, na swojej wiedzy, na swojej umiejętności, na swoim charakterze i swoim rozumie" 26 .

Niestety, jak zauważył przed laty Ignacy Matuszewski, główna trudność polskiej polityki zagranicznej leży w tym, że Polska nie może wyrzec się solidarności z państwami Zachodu, natomiast one łatwo wyrzekają się Polski ${ }^{27}$. One mogą sobie na to pozwolić, ona nie ma alternatywy, bo jej miejsce jest na Zachodzie.

Książkę Nowaka Pierwsza zdrada Zachodu. 1920 - zapomniany appeasement może spotkać zarzut, że jest polonocentryczna. Nie mamy jednak - jako historycy polscy - obowiązku dostosowywania naszych poglądów do oczekiwań czy przekonań naszych cudzoziemskich kolegów ${ }^{28}$. Historiografia polska winna przemawiać własnym głosem, bez kompleksów, ale zawsze oczywiście stosując zasadę audiatur et altera pars.

Monografia ma w tytule sformułowanie „zdrada”, ale książka - jak napisał we wstępie do niej jej Autor - nie jest „traktatem moralnym”. Nie jest usiłowaniem sądu nad twórcami polityki mocarstw cudzoziemskich, które nie mają obowiązku służyć interesom Polski. Jest wyłącznie analizą pewnego zjawiska z polityki międzynarodowej. A zjawisko to nie jest zamkniętą kartą historii. Może się powtórzyć w naszych czasach, o czym nas poucza choćby rosyjska agresja przeciw Ukrainie.

Znaczenie solidnie udokumentowanego dzieła Andrzeja Nowaka - przede wszystkim zupełnie nieznanymi archiwaliami brytyjskimi - widzieć należy na trzech polach historii stosunków międzynarodowych. Po pierwsze, odsłania nam ona ważną kartę z dziejów „wersalskiej” Europy, wprowadzając pojęcie brytyjskiego appeasementu wobec sowieckiej Rosji w roku 1920. Po drugie, przynosi wnikliwą rekonstrukcję podejścia elit Zachodu do odrodzonej Polski, będąc tym samym pracą z dziejów dwudziestowiecznej wyobraźni politycznej. Po trzecie wreszcie, ukazuje znaczenie polskiego zwycięstwa nad Wisłą w nowym świetle. Za jego sprawą ład wersalski został ocalony i uzupełniony pokojem ryskim, czego nie dostrzega historiografia narodów Zachodu.

${ }^{26}$ Wystąpienie wygłoszone w lutym 1982 r., drukowane w: XXV Rocznik Polskiego Towarzystwa Naukowego na Obczyźnie, 1981/1982, Londyn 1983, s. 16.

${ }^{27}$ I. Matuszewski, Pamięci Józefa Becka, w: idem, Wybór pism, New York 1952, s. 195.

${ }^{28}$ Przejmowanie z Zachodu teorii o „samobójstwie Europy”, którym miała być Wielka Wojna - jest błędem. Pisałem o tym ostatnio: „Prakatastrofa” Europy czy „wielki przełom w dziejach ludzkości”? (Nad stuletnią rocznica wybuchu Wielkiej Wojny), DN 2014, 3, s. $11-28$. 


\section{Streszczenie}

Artykuł jest komentarzem do nowej książki Andrzeja Nowaka Pierwsza zdrada Zachodu. 1920 - zapomniany appeasement (Kraków 2015). Monografia ta daje nową analizę międzynarodowych aspektów wojny polsko-sowieckiej (1919-1920). Znaczenie tej wojny było i jest bardzo często spychane na margines historii Europy, podczas gdy były to zmagania decydujące dla przyszłości kontynentu europejskiego, a przede wszystkim ładu wersalskiego. Nie sposób sobie nie wyobrazić jego załamania i sowietyzacji przynajmniej wschodniej i środkowej części Europy, gdyby wojna ta zakończyła się klęską armii polskiej. Książka Nowaka nie jest jednak analityczną monografią wojny polsko-sowieckiej, lecz studium nad ustosunkowaniem zwycięskich mocarstw Zachodu wobec tego konfliktu. Wśród tych mocarstw decydujące znaczenie odrywała Wielka Brytania. Autor doszedł do przekonania, iż w polityce tej wolno widzieć prefigurację późniejszego appeasementu z lat trzydziestych XX w. Rząd Zjednoczonego Królestwa czynił w 1920 r. wszystko, aby doprowadzić do ugody polsko-sowieckiej, która w istocie rzeczy byłaby równoznaczna $z$ hegemonią sowiecką nad odbudowaną Polską. Zwycięstwo armii polskiej w bitwie nad Wisłą udaremniło ten plan. Monografia ma w tytule sformułowanie „zdrada”, ale książka - jak napisał we wstępie do niej jej Autor - nie jest „traktatem moralnym”. Nie jest usiłowaniem sądu nad twórcami polityki mocarstw cudzoziemskich, które nie mają obowiązku służyć interesom Polski. Jest wyłącznie analizą pewnego zjawiska z polityki międzynarodowej. A zjawisko to nie jest zamkniętą kartą historii. Może się ono powtórzyć w naszych czasach. Książkę może spotkać zarzut, że jest polonocentryczna. Tak wszakże nie jest, bowiem Autor ma świadomość uwarunkowań polityki brytyjskiej i zawsze stosuje zasadę audiatur et altera pars. Książka Nowaka udokumentowana została nieznanymi (lub słabo zbadanymi) archiwaliami brytyjskimi. Autor wprowadza pojęcie brytyjskiego appeasementu wobec sowieckiej Rosji w roku 1920. Daje wnikliwą rekonstrukcję podejścia elit Zachodu do odrodzonej Polski, analizuje dzieje dwudziestowiecznej wyobraźni politycznej. Ukazuje także znaczenie polskiego zwycięstwa nad Wisłą w nowym świetle. Za jego sprawą ład wersalski został ocalony i uzupełniony pokojem ryskim (1921), czego często nie dostrzega historiografia narodów Zachodu.

\section{The First Treachery of the West. On the book by Andrzej Nowak}

The paper is a review of the new book by Andrzej Nowak Pierwsza zdrada Zachodu. 1920 - zapomniany appeasement (2015). The monograph provides a new analysis of the international aspects of the Polish-Soviet War (1919-1920). The conflict has often been marginalised in the history of Europe, while being decisive for the future shape of the European continent, and first and foremost for the Versailles governance. A collapse of the Versailles governance and sovietisation of at least Eastern and Central Europe are difficult to imagine but would have become a reality if the Polish-Soviet War had ended with a defeat for the Polish army. Nowak proposes a study of attitude of the winning Western superpowers to that conflict rather than an analytical monograph. Among the superpowers, Great Britain had 
the decisive voice. The author perceives the British policy as a prefiguration of appeasement applied in the 1930s. In 1920, the government of the United Kingdom used every effort to facilitate a Polish-Soviet settlement, what in fact would have turned into Soviet hegemony over reborn Poland. The victory of the Polish army in the Battle of Warsaw thwarted the plan. In spite of the word "treachery" in the title and as mentioned by the author in the introduction, the monograph is not a "treatise on morality". No attempt is made to judge the architects of foreign policies pursued by the world's superpowers, which have no obligation to serve the interest of Poland. The author merely undertakes an analysis of a phenomenon in international relations, which does not only belong to history, but continues to resonate throughout the world today. The book may be unfairly considered too Polocentric, yet the author shows awareness of the reality in which the British foreign policy was shaped, and always applies the audiatur et altera pars principle. The work is based on unknown or little examined British archive records. The author introduces the concept of appeasement towards the Soviet Russia in 1920. The book provides a thorough analysis of the attitude of Western elites to reborn Poland, and in this sense constitutes a review of the $20^{\text {th }}$ century political imagination. It casts a new light on Poland's victory in the Battle of Warsaw. Owing to this victory, the Versailles governance was saved and strengthened by the Treaty of Riga (1921) - a fact which remains unnoticed in the historiography of Western nations.

Translated by Paulina Dzwonnik

\section{Bibliografia}

Bainville Jacques, Les conséquences politiques de la paix, Nouvelle Librairie Nationale, Paris 1920.

Balcerak Wiesław, Na drodze do wojny. Europa Środkowo-Wschodnia wobec agresji niemieckiej i sowieckiej, w: Od Wersalu do Poczdamu. Sytuacja międzynarodowa Europy Środkowo-Wschodniej 1918-1945, red. Andrzej Koryn, Instytut Historii PAN, Warszawa 1996, s. 106-116.

Dąbski Jan, Pokój ryski. Wspomnienia, pertraktacje, tajne układy z Joffem, listy, Warszawa 1931.

Keynes John Maynard, Economic Consequences of the Peace, Macmillan \& Co., London 1919.

Kornat Marek, „Prakatastrofa” Europy czy „wielki przełom w dziejach ludzkości”? (Nad stuletnia rocznica wybuchu Wielkiej Wojny), DN 2014, 3, s. 11-28.

La guerre polono-soviétique de 1919-1920. Colloque, ed. Céline Gervais, Institut d'études slaves, Paris 1975.

Lloyd George David, The Truth about the Peace Treaties, London 1938, vol. 1-2.

Lord D'Abernon (Edgar), The Eighteenth Decisive Battle of the World. Warsaw, 1920, Hodder and Stoughton, London 1931.

Millerand Alexandre, Au sécours de la Pologne, „Revue de France” 12, 1932.

Nitti Francesco, L'Europe sans paix, Stock, Paris 1923. 
Nowak Andrzej, Pierwsza zdrada Zachodu. 1920 - zapomniany appeasement, Wydawnictwo Literackie, Kraków 2015.

Nowak Andrzej, Polska i trzy Rosje. Studium polityki wschodniej Józefa Piłsudskiego (do kwietnia 1920 roku), Arcana, Kraków 2001.

Raïssac Guy, Un soldat dans la tourmente, Editions Albin Michel, Paris 1963.

Skrzyński Aleksander, Poland and Peace, G. Allen \& Unwin Ltd., London 1924.

Smogorzewski Kazimierz, La Pologne restaurée, Gebethner i Wolff, Paris 1927.

Sukiennicki Wiktor, Balfour a Polska, „Zeszyty Historyczne” 1970, 17, s. 39-55.

Wandycz Piotr, General Weygand and the Battle of Warsaw of 1920, „Journal of Central European Affairs" 19, 1960, 4, s. 357-365.

Wereszycki Henryk, Niewygasła przeszłość. Refleksje i polemiki, Znak, Kraków 1987.

Zaleski August, Przemowy i deklaracje, t. 1-2, Warszawa 1929-1931.

Biogram: Marek Kornat (ur. 1971), historyk, profesor nauk humanistycznych, kierownik Zakładu Dziejów XX wieku w Instytucie Historii PAN w Warszawie oraz profesor na Wydziale Prawa i Administracji Uniwersytetu Kardynała Wyszyńskiego w Warszawie. Zajmuje się dziejami polskiej dyplomacji, ustrojami totalitarnymi, polityką międzynarodową XX w. oraz polską myślą polityczną XIX i XX w., kontakt: m_kornat@o2.pl 